\title{
Bibliotheca Universitatis Hafniensis Nogle randbemærkninger på falderebet
}

af førstebibliotekar Jørgen Thorning Sørensen

In omnibus requiem quaesivi, et nusquam inveni nisi in angulo cum libro

Thomas á Kempis

Jeg er fra forskellig side blevet opfordret til i kort form at sammenfatte Universitetsbibliotekets og Fiolstrædebygningens historie. Dette har mange andre jo skrevet om, så der er ikke så meget tale om nytænkning, men blot om en sammenfatning af læsning, kendsgerninger og personlige tilføjelser, en slags leksikonartikel, forhåbentlig til glæde for de, som følger efter.

\section{Middelalder og reformation}

Universitetsbiblioteket, der er Danmarks ældste videnskabelige bibliotek i egentlig forstand, blev grundlagt 1482. Som grundlægger regnes ifølge traditionen universitetets vicekansler, Peder Albertsen, som dette år skænkede Artes-fakultetet ved det nystartede Københavns Universitet (1479) en beskeden donation af bøger og håndskrifter, hvoraf titlerne på fire er kendt.

I 1497 fulgtes gaven op med endnu 24 værker, fortrinsvis inden for kanonisk ret, filosofi og medicin. I sandhed en beskeden start, men som man ser, grunden til et universalbibliotek. Det eneste eksisterende vidnesbyrd om det middelalderlige universitetsbibliotek er et håndskrift, nu i Gl. kgl. Saml. $18134^{\circ}$. Skriftet, der handler om geometri og astronomi, bærer på bindets inderside inskriptionen: Liber datus universitati per doctorem Petrum Alberti.

Men der havde været forgængere, således klosterbibliotekerne. Vi lader Torben Nielsen berette: (Elemente des Buch-und Bibliothekswesen, bd. 9, 1983) : 


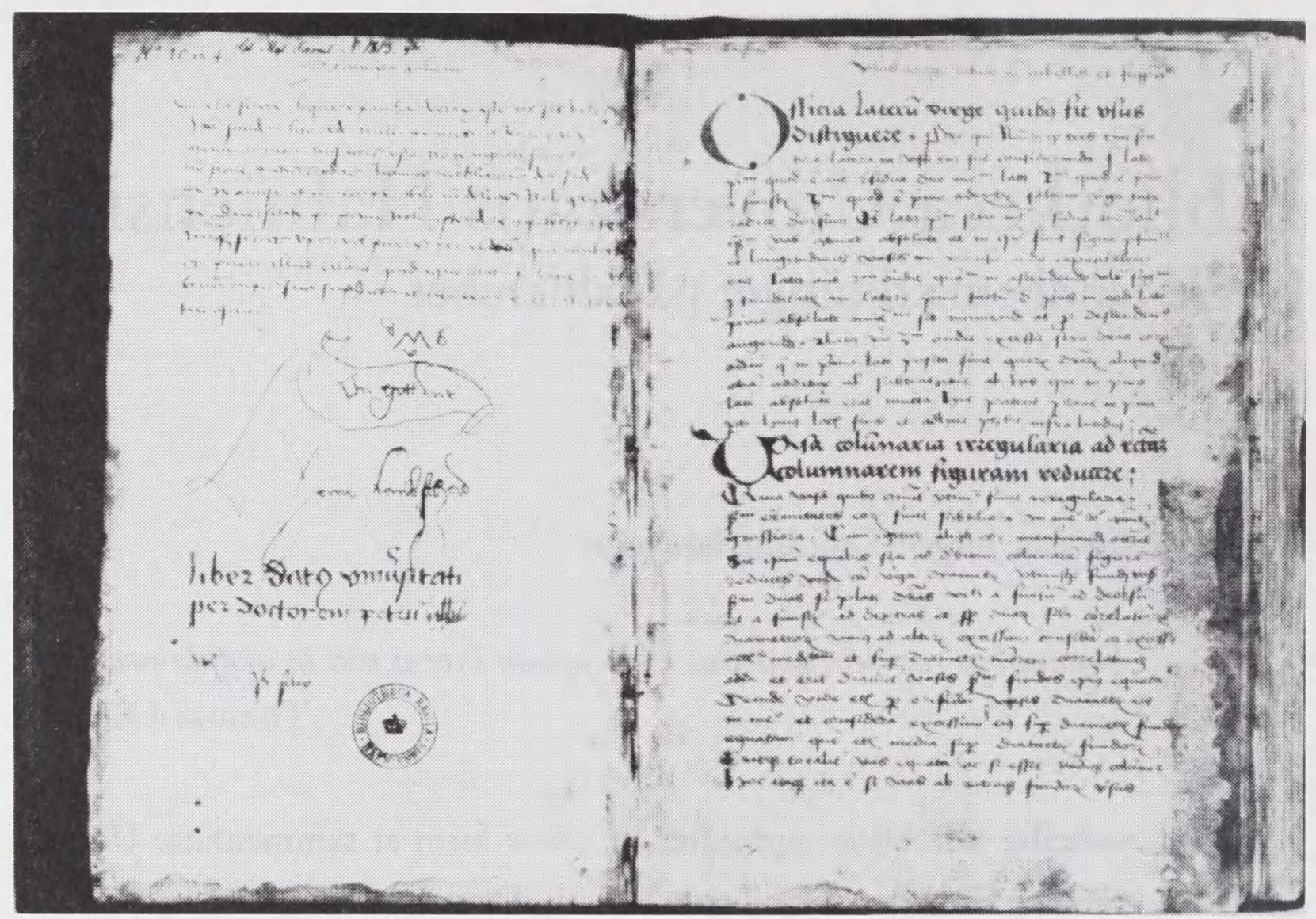

Det eneste håndskrift, der vides bevaret fra det middelalderlige Universitetsbibliotek, er Gl. Kgl. Saml. $18134^{\circ}$, hvis indhold er af geometrisk og astronomisk art. På bindets inderside notits om at det er en gave fra Peder Albertsen: Liber datus vniversitati per doctorem Petrum Alberti.

Vidnesbyrd om klosterbibliotekerne er bl.a. exlibris, hvoraf isar et fremheves, som findes i et Justinushåndskrift i KB. Det hedder: Liber sancte Marie de Sora. Per manum domini Absalonis archipiscopi. Justinus var ydermere forbillede for Absalons medarbejder, kronikeskriveren Saxo. Absalons efterfolger, Anders Sunesen, skankede ifolge liber daticus Lundensis 11228 "en kostelig skat" på 30 bind til arkebispesadet.

Men tilbage til Universitetsbiblioteket.

Ved Universitetets genoprettelse efter reformationen blev også bibliotekets forhold lagt i faste rammer i henhold til fundatsen af 1539. En egnet bygning stilledes i udsigt, og der blev ansat en medarbejder, som skulle besørge åbning og lukning, gå de besøgende til hånde og, måske vigtigst, holde opsyn. Vel nærmest en art kustode. Til boganskaffelser afsattes et årligt beløb på 50 rigsdaler, ikke noget svimlende beløb. Men det blev indskærpet, at den anskaffede litteratur skulle være alsidig. Det skulle ikke blot være teologi, men omfatte alle videnskaber, ja endog skønlitteratur. Professorerne forestod bogvalget.

Omkring 1540 bestod bibliotekets hovedsamlinger af to dele med forskellig proveniens: Arven fra det middelalderlige bibliotek og gaver fra velyndere, især Chr. 


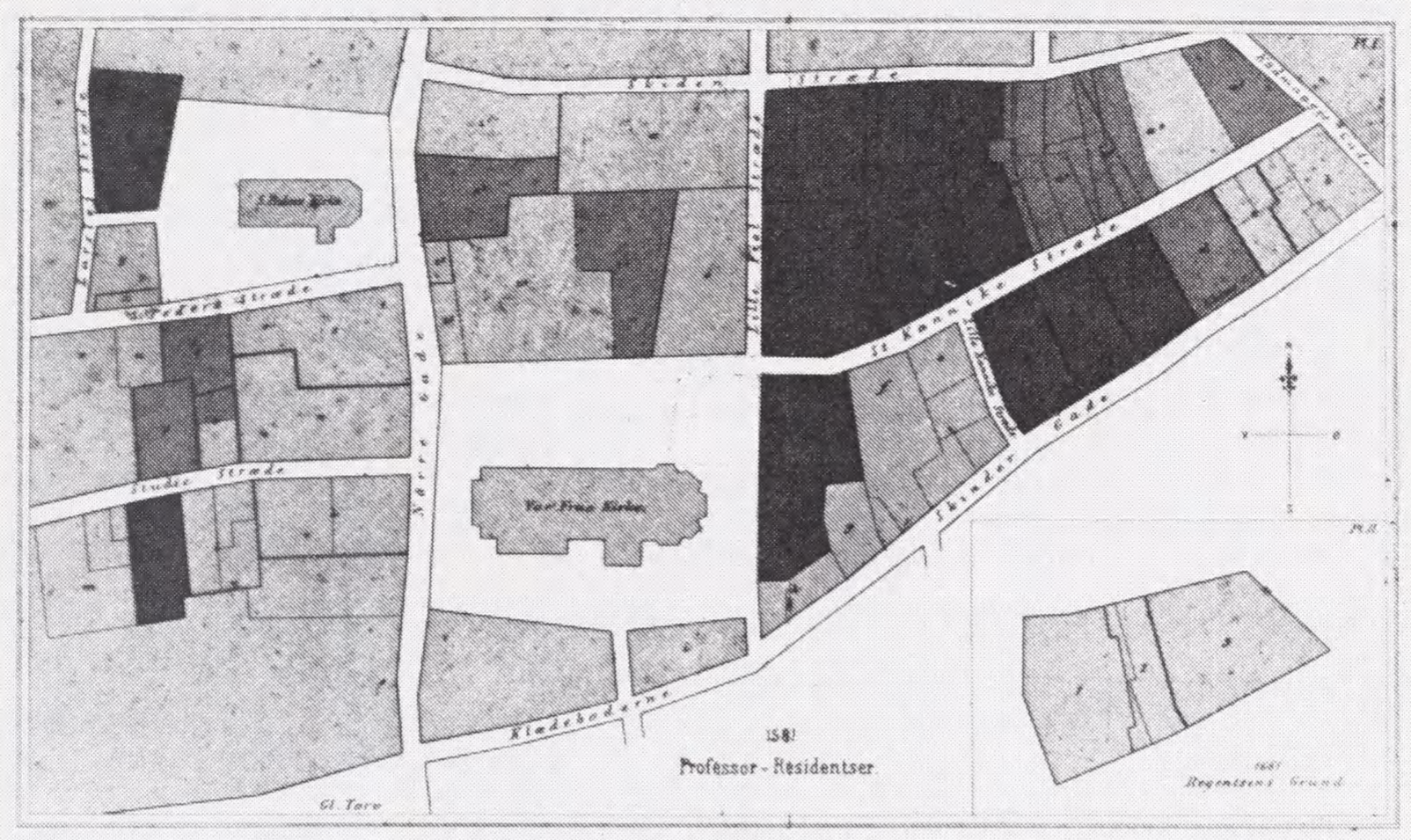

Plan over professorresidensernes beliggenhed i 1500-tallet. - De mørkeste områder markerer professorboliger -1581; de lidt lysere felter professorboliger før og efter 1581. De lyseste felter markerer nabogrunde. - Residenserne har med deres store haver omkring Store Kannikestræde lagt beslag på en anselig del af Klædebo Kvarter. I løbet af 1600-tallet dannedes tillige et professorkvarter imellem Studiestræde og Skt. Pedersstræde.

III, som var en stor bogelsker og som på Københavns Slot opbyggede et fortræffeligt bibliotek. Nu blev også klosterbibliotekerne indlemmet i Universitetsbiblioteket for at bruge et pænt ord. Et brev af 8. sept. 1537 giver den tyske magister Jørgen Thornman befuldmægtigelse til at rejse rundt i landet for i kirker og klostre at besigtige, registrere og udtage de bøger, som han fandt egnede "till thette liberiæ, som wij her aghttæ ath vprættæ." En større samling hidrørte således fra Voer Kloster. Den blev fragtet i tønder til hovedstaden, og hofprædikanten, som havde udtaget bøgerne, fik af professorerne nogle potter vin for sin ulejlighed. Denne og anden tilvækst gør igen byggesagen aktuel. Den ældste bygningshistorie fortaber sig i tåger, dog ved vi, at en del af samlingerne i 1543 flyttedes til St. Rochi Kapel ved Vor Frue Kirke. I 1554 kom samlingerne så omsider i hus, ikke som lovet i en egen bygning, men i det grundmurede hus, der var blevet opført langs Vor Frue Kirkegård på den nordlige del af nuværende Frue Plads. Husets stueetage blev brugt til auditorium, førstesalen som bibliotek. Her havde det til huse fra 1554 til 1652.

En egentlig katalog over samlingerne kendes først fra 1603, formentlig foran- 
lediget af professorernes uefterrettelighed. I hvert fald bad rektor om konsistoriums samtykke til at lade oprette "en rictige catalogus". Betegnelsen for dens indhold af bøger og håndskrifter blev Vetus Bibliotheca, for at holde de gamle samlinger adskilt fra nyere donationer. Oplysningerne heri er langt fra fyldestgørende, men katalogen tjener dog som en væsentlig kilde til bibliotekets historie i det 16. århundrede.

Bøgerne har i almindelighed været indbundne eller forsynet med pergamentomslag. Den overvejende del har været latinske udgaver og en del græske, men værker på nationalsprogene fandtes da også, således f.eks. Luthers bibeloversættelse. På dansk kun et fåtal, bl.a. Saxo, Povl Helgesen og Niels Hemmingsen. Klenodiet er Rimkrøniken, den første trykte bog på dansk.

Lidt statistik over samlingernes sammensætning:

\begin{tabular}{|lc|}
\hline Fagfordeling & Bøger og værker \\
\hline Libri theologici & 252 \\
Libri medici & 25 \\
Libri philosophi et historici & 151 \\
Libri juridici & 26 \\
Appendix librorum theologicorum & 75 \\
Appendix librorum in utroqve jure & 146 \\
Bøger og værker ialt & 675 \\
\hline
\end{tabular}

Som det fremgår af fagdelingstabellen, er teologien som forventeligt dominerende. Dernæst følger jura, dog med flest titler i Appendix, som rummer en mængde kirkeret. Dernæst følger de humanistiske discipliner, mens medicinen og juraen på dette tidspunkt er klart dårligst repræsenteret.

\begin{tabular}{|lrrrr|}
\hline Fagfordeling & før 1529 & $1529-59$ & 1560-1603 & lalt \\
\hline Teologi & 211 & 35 & 6 & 252 \\
Medicin & 6 & 19 & 0 & 25 \\
Artesfagene & 92 & 55 & 4 & 151 \\
Jura & 22 & 4 & 0 & 26 \\
Appendix: teologi & 75 & 0 & 0 & 75 \\
Appendix: jura & 146 & 0 & 0 & 146 \\
Bøger og værker ialt & 552 & 113 & 10 & 675 \\
Omregnet til bind, ialt ca. & 828 & 169 & 22 & 1019 \\
\hline
\end{tabular}

Ser man på skemaet over fordelingen på trykår, viser det sig, at klart den overvejende del af samlingerne er fra før 1529. 


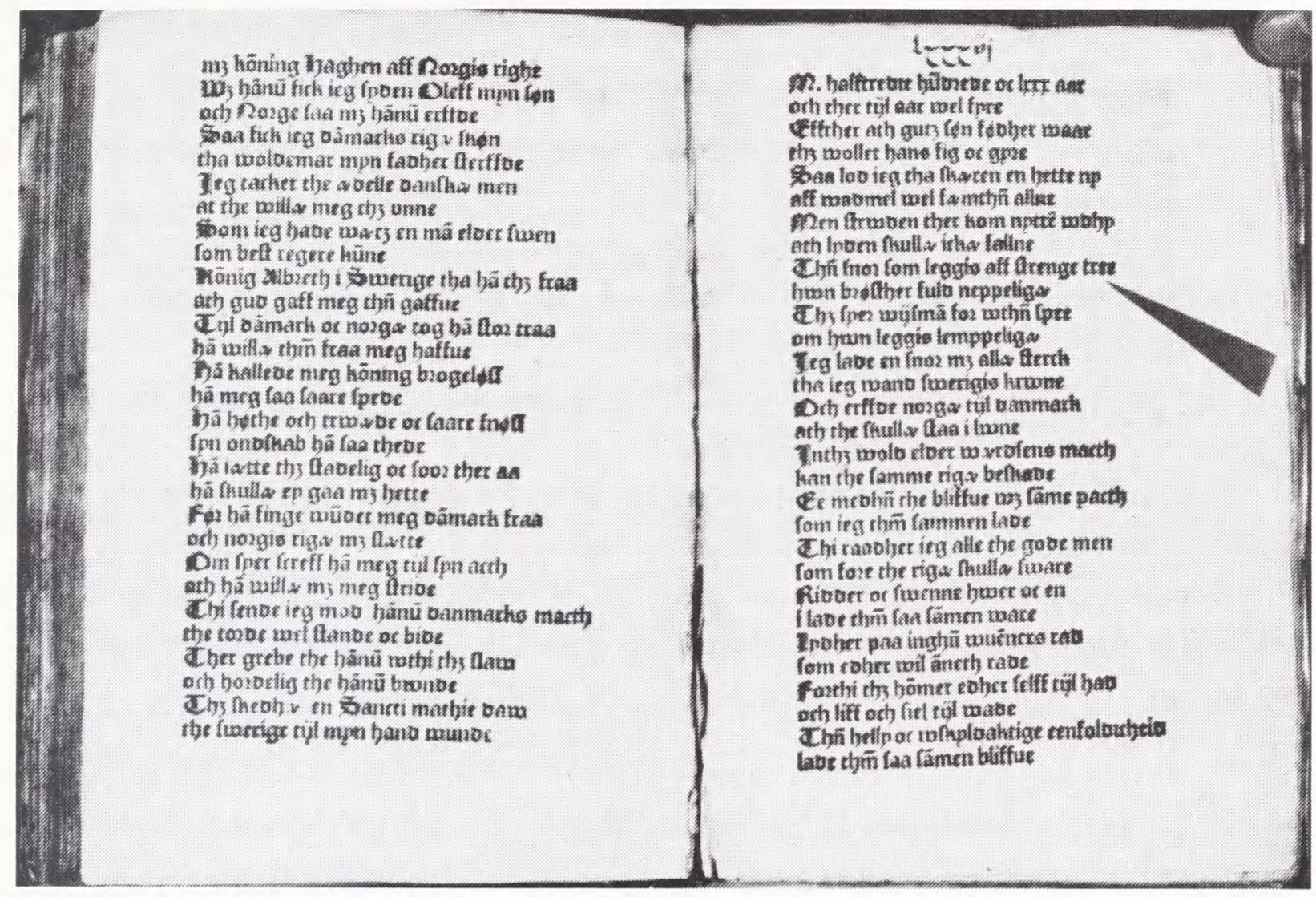

Arild Huitfeldt (1546-1609) skrev den første Danmarkshistorie på dansk. Den omhandlede perioden fra kong Dan til Frederik 2 og udkom 1594-1604 i 10 kvartbind.

\section{Tiden 1603-1654}

I 1600-tallet opbyggedes betragtelige privatbiblioteker, ekempelvis af universitetets professorer. Vi kan nævne professor i dialektik Johannes Stephanius, der opbyggede en fin bogsamling, sprogforskeren Jacob Madsen Aarhus, som bl.a. erhvervede o. 175 håndskrifter, og sidst, men ikke mindst, kronen på værket, medicin-professor Anders Lemvigs store samling, som ved hans død omfattede 1864 bind eller ca. 3.000 titler, idet der ofte var flere bibliografiske enheder i samme bind. Værdien anslog Lemvig selv til 400 daler. Denne ypperlige samling, som indeholdt mange danske ting, tilfaldt ved Lemvigs død i 1603 Universitetsbiblioteket, som det jo både da og senere var tilfældet med mange private samlinger. Lemvigs donation indleder bibliotekets glansperiode, som varede de næste hundrede år. Med donationen fulgte iøvrigt tre bogskabe, to borde samt diverse stole og stiger. Samlingens omfang nødvendiggjorde en udvidelse af biblioteket, som nu fik råderet over to etager, nederst det gamle bibliotek, ovenpå Lemvigs samlinger.

Hans Poulsen Resen forestod både reorganiseringen og en ny katalog over, som det hed, Bibliotheca Lymviciana. 
Samtidig vedtoges et sæt love, det første kendte reglement for universitetsbibliotekaren. Det var på latin, men lyder i oversættelse:

Bibliotekaren, hvem bogerne er betroet af Rector Magnificus og professorerne, skal omhyggeligt sorge for, at alt er velholdt og rent.

Han skal også afvarge, at bogernes orden forstyrres, så de ikke svarer til katalogen.

Han må ikke tillade nogen at låne mere end $i$ det hojeste fire boger af gangen, for at biblioteket ikke skal synes helt raseret.

Hver måned skal han fordre disse tilbage og i mellemtiden fore hver enkelt ind i en bog, der er bestemt til regnskab af den art.

Han skal årligt for hundedagene aflegge regnskab for Rector Magnificus og Decanus og erstatte tab (sic!), hvis sadanne konstateres.

Hver gang en ny bibliotekar ansattes, skal han modtage biblioteket efter katalogen og straks underskrive med sit navn på dette sted for at indprente sig, at han er forpligtet af ovenstående.

Accessionen i disse år var fremdeles en blanding af køb og gaver. Januar 1605 indtraf en vigtig begivenhed, da Christian IV skænkede Universitetsbiblioteket samlingerne fra Københavns Slot, ialt 1.070 bind, navnlig bøger trykt før 1559. Blandt værkerne var hele Luthers forfatterskab samt store dele af den øvrige reformationslitteratur. Alle fagområder var repræsenteret. Bøgerne var smukt indbundne, undertiden i fløjlsbind og med sølvspænder. Også en del håndskrifter indgik, men deres betydning er uvis. Bibliotekets bestand var herefter henved 4.000 bind. Sammenligner man med udenlandske biblioteker, havde Bodleian Library på omtrent samme tid 7.500 bind, men det var dog efter tidens målestok ingen ringe bogbestand.

Mindst ligeså betydningsfuld var imidlertid indførelsen af pligtafleveringen. Fra 1631 eksisterede der to universitetsbogtrykkere, som nød forskellige privilegier, men til gengæld også havde pligter, f.eks. at levere fritryk af professorernes theses.

Fra 17. dec. 1623 blev det ved Konsistoriums beslutning fastslået, at universitetsbogtrykker Salomon Sartor skulle afgive et eksemplar af alt, hvad han lod trykke, til biblioteket. Herved var pligtafleveringen indført i Danmark. Dette blev naturligvis af uvurderlig betydning for eftertiden, men skabte som bekendt også visse pladsproblemer! Hertil kom håndskrifterne, hvoraf Resen selv skænkede en del. Af stor betydning for forskningen blev det, at de kongelige historiografers arkivalier ved kongelig ordre blev afleveret til Universitetsbiblioteket i 1618-20. Dette værdifulde kildemateriale gik dog totalt tabt ved bibliotekets brand i 1728 . 
De af kongen skænkede samlinger, Bibliotheca Regia kaldet, fik efterhånden status som bibliotekets hovedsamlinger, hvori også den nye pligtaflevering indgik. Det hedder således i afleveringsdokumentet af 1626:

Anno 1626 den 23 Septemb. bleff diese forskreffne boger leffueret på Universitets Bibliothek, och findis nu skreffuit vdj Catalogum Regie bibliothece ...

Retskrivningen havde vore kære forfædre, som det ses, stadig ikke fået styr på, men morsomt er det da.

Købene var stadig beskedne, et pålæg fra kansleren i 1651 satte sig ingen spor. Gennem en længere årrække ses slet intet købt. - Imidlertid kan indlemmelsen af håndskrifterne og indførelsen af pligtafleveringen ses som skridt henimod etableringen af Universitetsbiblioteket som nationalbibliotek. Biblioteket var på dette tidspunkt reelt rigets centrale hovedbibliotek.

Lånevilkårene er ufuldstændigt oplyst, men var naturligvis restriktive. Særlige ønsker om hjemlån blev nok kun efterkommet, når lånerens sociale position tilsagde det, som da Konsistorium bevilgede kgl. livlæge Henning Arnisæus nogle bøger til låns i to måneder. Lignende tilladelser kunne f.eks. opnås af professorerne ved Sorø Akademi, men ellers var brugen forbeholdt universitetets professorer. Visse længerevarende udlån er dog registreret, som da Peter Spormand, professor i geografi, lånte 16 bind, som først blev afleveret af arvingerne ved hans død! Men det var undtagelser.

Blandt de flittige brugere var Ole Worm, som var blandt de første, der bragte håndskrifter fra samlingerne i trykken. Bl.a. besørgede han en udgave af Heimskringla. 1645 fulgte Stephan Stephanius' berømmede Saxoudgave med et væld af noter og kommentarer. Samme herre udarbejdede udførlige registranter over indholdet af diverse håndskrifter, bl.a. nu tabte brevbøger fra Middelalderen.

\section{Trinitatis kirkeloft}

Sidst på året 1636 begyndte opførelsen af Chr. IV's Trinitatis Kirke. Det besluttedes, at Universitetsbiblioteket skulle have til huse i loftsrummet over kirken, vel verdens mest mærkværdige placering af et bibliotek. I 1650 var byggeriet nået så vidt, at indretningen af bibliotekssalen kunne begynde. I 1652 flyttedes bøgerne herhen. 
Der eksisterer ingen samtidige eller senere afbildninger af bibliotekssalen på Trinitatis kirkeloft, men vi kan danne os et indtryk gennem de skriftlige kilder.

Når man ville på Universitetsbiblioteket dengang, passerede man først en række runestene ved Trinitatis Kirkegård, foranlediget opstillet af Ole Worm. Derefter gik vejen op ad Rundetårns rotunde. Kirken skulle på én gang tjene tre formål: Studenterkirke, astronomisk laboratorium og bibliotek.

Den store bibliotekssal var godt 50 meter lang og $20 \mathrm{~m}$ bred. Interiøret var festligt: Gult bræddeloft, båret af rødmalede bjælker, og langs væggene store bogskabe med påmalede billeder og inskriptioner. Det har været farverigt!

Med en samtidig besøgendes egne ord:

Naar mand der indkommer, da er at see paa begge Sider store Boge-Skaff oc it langt Boer rot anstrogen med Bencke hos, oc er hvert Bogskaff med 4 Dore for affdelet, de tvende offuerste Døre er med Staaltraad betecket, at mand kan see Bogerne, som derinde staar, de underste ere udi Panille giort, paa hvilcke er at see malet adskillige merchelige oc underlige Historier oc Latine oc danske artige Emblematis.

Gult, rødt og grønt var grundfarverne, og på bogskabenes nederste fyldninger var malet allegoriske billeder samt tankesprog og sentenser til almindelig opbyggelse. Her citeres:

-Hvo meget unyttigt lase vil, med Boger bruger kun Abespil.

-Tag Bogen fat, baade Dag og Nat

-Min Ven, kom her, les det, godt er

-Spindelvavstanker kun Fluerne sanker

Skabene var forsynet med skilte, der angav indholdet, som i Rosens Navn. På skabene hang de dertil hørende kataloger i træbind med messingbeslag. Vinduesnicherne var prydet med portrætter af lærde og donatorer. Et læsehjul, som kendt fra andre biblioteker i Europa, var her også - så kunne man læse flere bøger på én gang. Iøvrigt kunne bøgerne lænkes til læsepultene, en effektiv foranstaltning mod eventuelle tyverier.

Bibliotekets daværende leder, Thomas Bang, anlagde en smukt dekoreret og stadig eksisterende gavebog, som de gamle havde gjort. Med bind i rødt fløjl og graverede sølvemblemer.

1656 indviedes bibliotekssalen på Trinitatis kirkeloft ved en højtidelighed, bivånet af kongen og hans følge. Klokkerne kimede, Bang holdt indvielsestalen, og der blev musiceret og afholdt tablauer, som skulle markere bibliotekets åbning. 


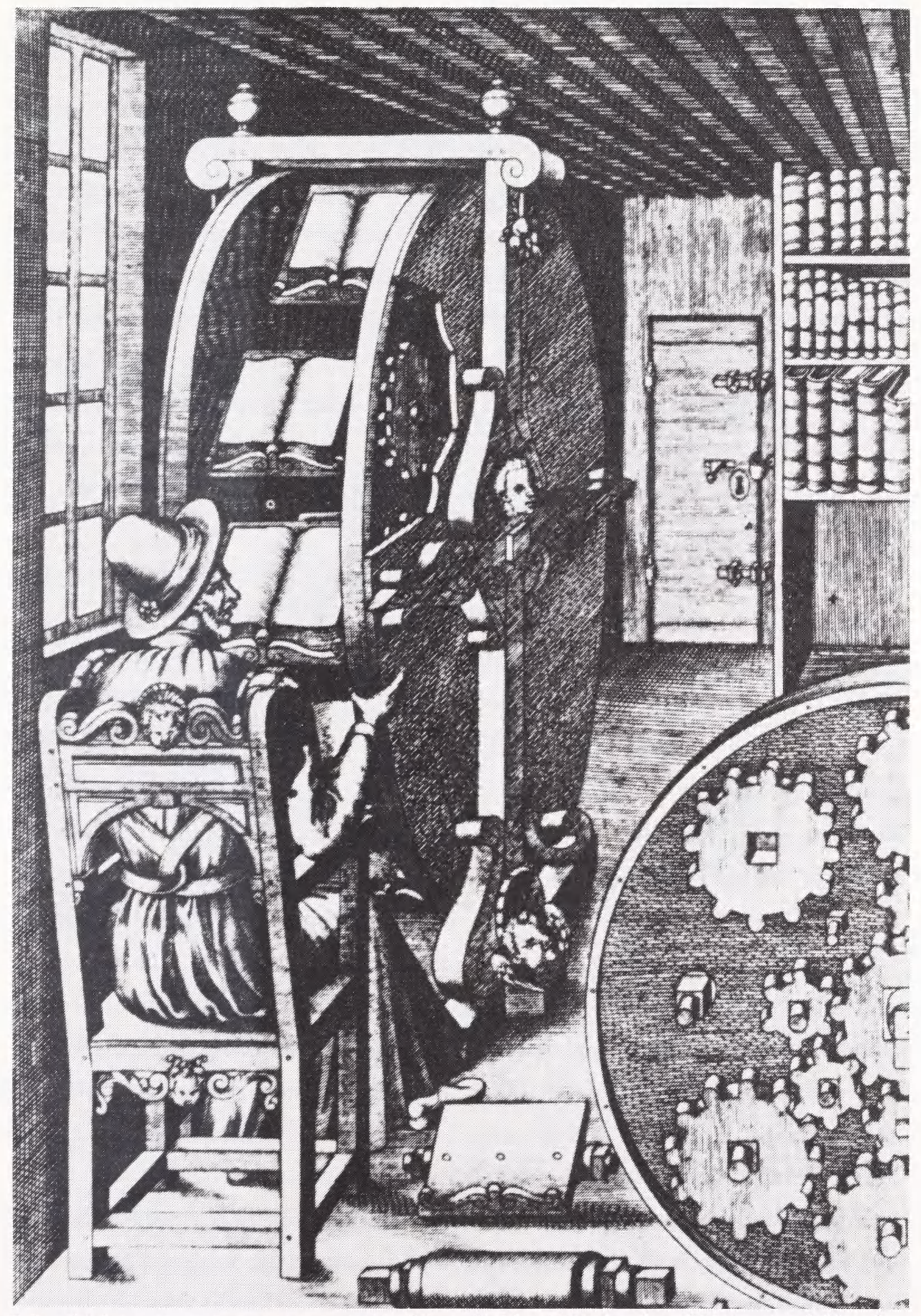

Et læsehjul som dette, konstrueret o. 1588 af Ramelli, blev 1653 skænket til Universitetsbiblioteket og vedblev indtil 1728 med at være en af dets seværdigheder. 
Bibliotekssalen på Trinitatis kirkeloft har siden rummet flere funktioner, bl.a. malersal for Det kgl. Teater. I dag er den nyrestaureret og ramme om mange udstillinger, også fra Det kongelige Bibliotek. Den står smukt med sine restaurerede bjælkelofter. Men idag uden bemaling. Som vor i visse henseender asketiske tid foreskriver.

Samtidig med flytningen til Trinitatis kirkeloft blev Universitetsbiblioteket erklæret for et publicum Museum, dvs. et offentligt bibliotek, hvortil adgang ganske vist var betinget af akademisk borgerskab, men hvortil både lærere og studerende nu havde adgang. Nye love fastsatte åbning nogle timer hver onsdag og lørdag, i augustferien dog alle hverdage. Udlån var udelukket, hvilket professorerne dog næppe følte sig bundet af, men læsesalsforholdene blev stærkt forbedret i den nye sal. Benyttelse af biblioteket registreredes dels i en besøgsprotokol, dels i en Librarius Nomenclator, hvor låneren selv noterede de benyttede titler, og hvorfra han atter udnoteredes, når bøgerne blev leveret uskadt tilbage.

Flytningen medførte også en procentuelt set betydelig personaleudvidelse, idet overbibliotekaren nu suppleredes med en vicebibliothecarius, hvis fornemste opgaver var tilsyn med biblioteket i åbningstiden, samt efter 1653 administration af pligtafleveringen. Hertil kom to studentermedhjælpere, famuli, hvis hovedbeskæftigelse formentlig var fremtagning og påpladssætning.

Efterhånden blev Underbibliotekarstillingen den mest betydningsfulde, alene af den grund, at Overbibliotekaren ikke valgtes ud fra bibliotekariske kvalifikationer, men efter dekret af 1690 besattes med "senium academicum." Så han har nok mestendels svævet over vandene. Det var da også Underbibliotekaren, der forestod de i slutningen af 17. århundrede iværksatte revisioner.

Det kneb efterhånden med overblikket over bibliotekets indhold, som var registreret i flere forskellige kataloger eller slet ikke. Derfor iværksattes et nyt katalogarbejde, hvis drivende kraft var Thomas Bartholin, meget aktiv overbibliotekar i årene 1671-80. Resultatet af dette arbejde kan ses i oversigten på næste side over Universitetsbibliotekets samlinger 1662.

Biblioteket levede stadig højt på private gaver. Kongelige donationer skulle man ikke længere regne med, da Frederik III var i fuld gang med at opbygge sit eget Store kongelige Bibliotek.

Blandt tidens boggaver kan især nævnes økonomen Hans Mules samling på henved 7.000 bind, og Henrik Fiurens gave på over 1.600 bind medicinsk og matematisk 


\begin{tabular}{|c|c|c|c|}
\hline Samlinger & Antal skabe & Håndskrifter & Bøge \\
\hline I. Vetus Bibliotheca & 3 & & o. 1000 \\
\hline 2. Bibliotheca Lymviciana & 2 & & 1864 \\
\hline 3. Bibliotheca Regia (med App.) & 2 & & 1197 \\
\hline 4. Bibliotheca Brochmanniana & 7 & & 3994 \\
\hline 5. Bibliotheca Gelstrupii & - & & --- \\
\hline 6. Bibliotehca Fuireniana & 2 & & 2042 \\
\hline 7. Capsa Tertullani & 1 & 108 & \\
\hline Capsa Cypriani & 1 & 149 & \\
\hline Capsa Ambrosii & 1 & 292 & \\
\hline Capsa Originis: Pars I & $1 / 2$ & 20 & 45 \\
\hline Capsa Orginis: Pars 2 & $1 / 2$ & & 312 \\
\hline Capsa Mosis & 1 & 81 & \\
\hline Capsa inferior Australis & $1 / 2$ & & 120 \\
\hline Capsa inferior Borealis & $1 / 2$ & & 53 \\
\hline 8. Afleveret fra Peder Spormand & bo & & 16 \\
\hline \multicolumn{4}{|l|}{ Skabe og bind ialt, } \\
\hline excl. Bibliotehca Gelstrupii & 22 & 650 & o. 10643 \\
\hline
\end{tabular}

litteratur, modtaget 1674, senere forøget med 7.600 fra samme familie. Denne enorme tilvækst gav pladsproblemer, hvilket dels førte til auktionssalg af en del dubletter, dels til udflytning af dele af samlingerne til en nybygning ved Frue Kirke.

Til de store donationer føjedes yderligere juristen Peder Hansen Resens store Bibliotheca Reseniana på mindst 7.000 bibliografiske enheder, bibliotekets væsentligste udvidelse før 1728.

Men det genskabte Kongens Bibliotek var blevet en konkurrent. Den nye bogtrykkeraflevering af 1697, omfattende hele kongeriget, gjaldt således Det kongelige Bibliotek (KB) og ikke Universitetsbiblioteket (UB). Grunden var lagt til et nationalbibliotek, adskilt fra Universitetsbiblioteket.

Først ca. 300 år senere tog man konsekvensen af den her påbegyndte udvikling og sammenlagde de to institutioner. 


\section{Katastrofen 1728}

Onsdag den 21. oktober $1728 \mathrm{kl}$. 7 om aftenen, udbrød der en voldsom brand i København, som stod på i hele 3 dage.

Vi citerer i det følgende brudstykker af en øjenvidneskildring, betitlet "Relation, hvorledes det med den ulykkelige Ildebrand i Kiøbenhavn den 21de, 22de, og 23de October 1728 sig haver tildraget" - en slags datidens avis. (Optrykt i Journal for Politik, Natur-og Menneske-Kundskab, bd. 5, 1811, p. 115 ff.)

Ilden antendtes $i$ et lidet Huus paa det sondre Hiorne af Vestergade, hos en Marquetenter og Lysestober. Ved Undersogning er det befundet, at et Barn har havt sit Legetøi ovenpaa Loftet, og havde udi det paa Loftet liggende Høe forglemt det; og da Barnet det samme med Lys ville hente, er dette i Hoet nedfaldet ...

Vinden var den Tid meget sterk af Vesten, og bar altsaa lige paa Byen; den holdt ved den ganske Nat og paafolgende Dag, saavel som den derpaa folgende Nat, ikke paa een Kant, men sprang tidt og ofte hen til Sydvest og Nordvest med bestandige igiennemtrangende og hvirvelagtige Stod, hvorved Ilden immerfort til hoire og venstre Side videre udbredede sig, ja mangengang ganske imod Vinden blev fordrevet.

Bedre blev det ikke af, at byens vandforsyning var delvis afbrudt og brandfolkene ifølge vor kilde berusede.

Næste dag bredte ilden sig til latinerkvarteret. Frue Kirke brændte først på formiddagen. Hen på eftermiddagen nåede branden Trinitatis. Kl. fem begyndte tårnet at brænde for alvor, og ved midnat var biblioteket omspændt af flammer. Da branden ebbede ud, var Universitetsbibliotekets uvurdelige skatte af bøger og håndskrifter, på nær nogle få udlånte, blevet flammernes bytte.

Professorerne havde reddet noget af deres privatbiblioteker. Af kollegiebibliotekerne var kun Valkendorfs tilbage. Katastrofen var noget nær total.

Men kongernes bibliotek på Københavns Slot var da heldigvis uberørt af branden. Men det lå jo også længere væk. Helt henne i Frederiksholms Kanal. Men Det kongelige Bibliotek var jo endnu, i sin egenskab af lukket hofbibliotek, mindre væsentligt i sammenhængen. Nekrologen blev skrevet kort og lakonisk af underbibliotekaren Arne Magnusson, hvis islandske håndskrifter heldigvis blev bragt i sikkerhed:

I Bibliotheket oven på Trinitatis Kirke vare mange Ting, som Verden nu ikke mere eier, hvilken Skade kan ikke afhielpes.

En forholdsvis velplejet kulturarv var med få undtagelser definitivt gået til grunde. 35000 bd. bøger og håndskrifter blev flammernes bytte. For kilderne til Danmarks historie var det det største samlede tab nogensinde. Sic transit gloria mundi ... 




Opgangen gennem Rundetårn til bogsalen på Trinitatis kirkeloft. Akvarel af H.G.F. Holm, kaldet Fattig-Holm (1803-61). Sign. Holm (grafitti på muren). Ca. 1835.

Ovennævnte kilde opregner afslutningsvis ødelæggelserne i de enkelte kvarterer af byen. Om "Kiøbmager Quarteer", hedder det således:

Kiøbmagergade, den ene Side til Raadmand Klinges Gaard øde. Den anden Side ganske ode til Hiornet af Silkegade, hvor Jean Viintapper boede. Klareboderne ganske øde. Silkegaden, den ene Side, ganske ode, indtil Statsraad Fosses Gaard, som er ruineret. Pilestrade, 4 Huse opbrandte, og en Deel ruineret. Lille Regnegade den ene Side ode. Store Regnegade, den ene Side ode. Gammelmynt ganske ode. Myntergaden iligemaade opbrandt.

Til slut opregnes den samlede skade: Foruden Vor Fruekirke, Helliggeistes, Tydske Kirke, Trinitatis, Reformert, Vaisenhuus-Kirker, Raadhuset, Residenzerne, saa og Biskoppens, Presternes og Professorernes Gaarde, ialt 1640 brendte - 39 ruinerte.

\section{Genopbygningen}

De omfattende skader, branden havde forvoldt, virkede naturligvis lammende på såvel statsmagt som bystyre, og Universitetsbibliotekets genopbygning har næppe haft højest prioritet. Igen var det kongen, der kom det nødstedte bibliotek til 
undsætning, idet Frederik IV ved gavebrev af 30. juni 1730 skænkede mere end 2000 dubletter fra sit eget bibliotek.

Blandt andre vigtige donationer skal nævnes Arne Magnussons testamenterede håndskriftsamling, som dog var universitetets eje. Den forblev i Universitetsbiblioteket indtil 1930. En pengegave fra universitetspatron Iver Rosenkrantz satte biblioteket i stand til at købe 103 folianter og 62 kvarter inden for teologi og filologi.

Allerede et par år efter branden stod man med betydelige samlinger og sommeren 1733 kunne bogsalen på Trinitatis kirkeloft igen tages i brug. Der opstilledes 4 meter høje, aflåselige bogskabe i to dobbeltrækker parallelt med ydermurene i den $25 \mathrm{~m}$ lange sal. Ved vinduerne stod borde og bænke til de læsende. I korenden fik manuskripterne plads.

En ny fundats af 1732 fastsatte blandt mange andre ting, at biblioteket skulle holde åbent alle hverdage undtagen fredag fra 8-10 og 14-16. Hjemlån var stadig forbeholdt professorerne. Fjernede en student en bog, blev han relegeret.

Iøvrigt fastslog fundatsen, at der skulle forelæses i håndbogs- og biblioteksbenyttelse! Men det blev næppe efterlevet i noget større omfang.

Budgettet varierede meget fra år til år, så det var vanskeligt at fastlægge en anskaffelsespolitik. Den faste årlige bevilling var 400 Rdl., men hertil kom bøder, legater og diverse donationer. Desuden købtes der en del på auktioner, såvel udenlandske som danske bøger. Blandt samlinger, som erhvervedes i disse år, kan nævnes Thomas Bartholins og Jacob Bircherods samt den såkaldte Franckenauske samling af især tyske salmebøger og manuskripter. 1745 skænkede Frederik Rostgaard hele sin bog- og håndskriftsamling til biblioteket, ialt 1100 trykte bøger og 500 manuskripter. Bogsamlingen omfattede næsten alle fag, dog med hovedvægt på historie, filologi og skønlitteratur. Det var ved denne lejlighed man erhvervede Rimkrøniken i det i dag eneste kendte komplette eksemplar. Håndskrifterne var mest af nationalhistorisk art. Interessant er et håndskrift af Jyske Lov fra 15. årh. i såkaldt posebind.

I 1753 blev pligtafleveringsordningen udvidet til igen at omfatte Universitetsbiblioteket, hvilket skabte grundlaget for opbygningen af den store danske samling, som er udbygget helt op til vore dage, og som idag indgår i Det kongelige Biblioteks universitetsbiblioteksafdeling.

Adgangen til samlingerne var som sagt restriktiv. Dog blev man en del generet af 
besøg af almindelige gæster i Rundetårn. I 1752 ansattes derfor en tårnvægter, som i åbningstiden skulle "hindre adskillig Uleilighed af Børn og liderlig Almue"!

1770 ansattes en ny universitetsbibliotekar, filologen og historikeren Abraham Kall, der havde været ansat ved universitetsbiblioteket i Göttingen, som var kendt for sin gode organisation.

Kall gennemførte i perioden 1770-80 en lang række reformer, navnlig hvad angår bogsalens indretning. Det detaljerede ombygningsprogram indebar bl.a., at bogskabene erstattedes af åbne reoler, idet der samtidig indrettedes et læseværelse. For at gøre det brugbart også om vinteren, blev det forsynet med en kakkelovn! Ved indretningen af 'læsesalen' indstiftedes adskillelsen af publikumslokaler fra bogmagasin, et princip som videreførtes i Fiolstræde, og som først blev brudt med Amagerfilialen i 1978.

Ombygningen medførte en øget hyldekapacitet, så salen nu kunne rumme ca. 100.000 bd., hvor den øjeblikkelige bogbestand var på ca. det halve. Der skulle dog ikke gå mere end et halvt århundrede, før pladsproblemerne igen meldte sig.

En stor tilvækst skete i 1770, da man købte professor J.A. Fabricius' 20.000 bd. store samling af klassica samt 440 manuskripter. Fem år senere modtog biblioteket fra den danske konsul i Bordeaux, Hansen de Liliendal, ca. 800 værdifulde franske værker, og 1774 erhvervedes en samling af over 10.000 tyske disputatser, benævnt Lintrups Samling.

Ved Kalls afgang 1780 havde Universitetsbiblioteket et hæderligt, men svingende budget. Det blev nu betragtet som et selvstændigt institut med ret til at overføre penge fra det ene finansår til det andet. Kapitalen var således i 179518.000 Rdl.

\section{Det 19. århundrede}

1793 blev Det kongelige Bibliotek åbnet for offentligheden, og dette ændrede bibliotekssituationen i København radikalt. Den videnskabelige offentlighed havde nu to store biblioteker til rådighed, begge i princippet universalbiblioteker. Dette forhold afspejler sig i de næste 200 års debat om de videnskabelige biblioteker og munder ud i sammenslutningen af de to biblioteker i 1990.

1796 blev Rasmus Nyerup ansat som underbibliotekar ved Universitetsbiblioteket, fra 1803 blev han dets formelle leder. Dette fik stor betydning for bibliotekets muligheder for at spille en rolle i det nye biblioteksbillede, som også rummede 


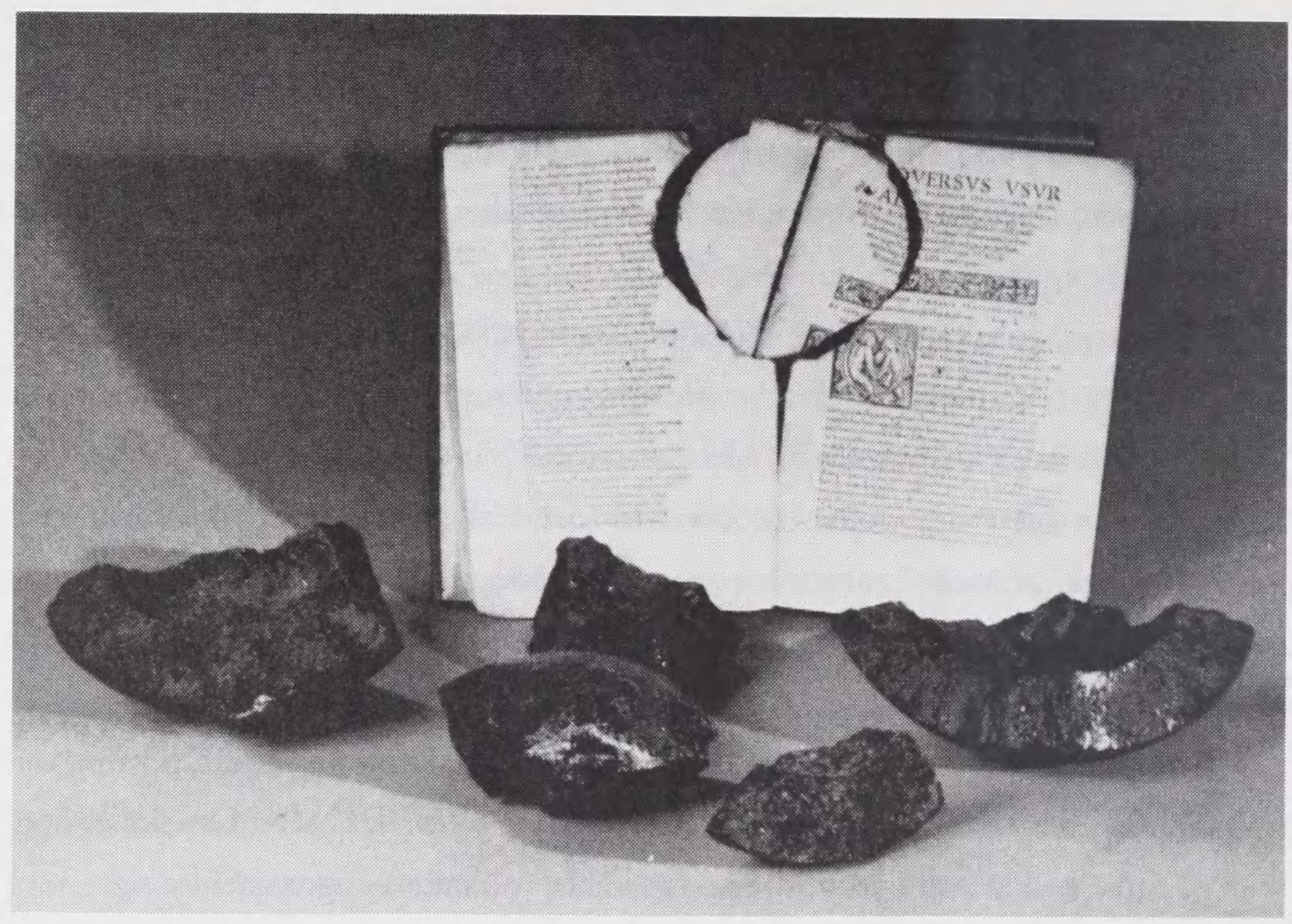

Marsilius af Padua: Defensor Pacis, Basel 1522, efter bombardementet i 1807.

nystartede videnskabelige fagbiblioteker som Botanisk Haves Bibliotek, Veterinærskolens Bibliotek, Kunstakademiets Bibliotek, de militære biblioteker og Kirurgisk Akademi i Bredgade. Hertil kom privatbiblioteker som det Classenske Bibliotek, senere indlemmet i Universitetsbiblioteket, samt kollegiebibliotekerne.

Nyerup blev Universitetsbibliotekets næste store reformator og den første overbibliotekar, som kan siges at have en egentlig bibliotekarisk uddannelse.

Nyerup kom som tyveårig i huset hos den da nyudnævnte overbibliotekar ved Det kongelige Bibliotek, J.H. Schlegel og fik i de følgende år en grundig biblioteksuddannelse, både under Schlegel og hans efterfølgere, Erichsen og Moldenhawer. Han var således godt rustet til at overtage ledelsen af biblioteket på kirkeloftet, eller som Molbech senere udtrykker det:

Her, paa denne, ved sit Sted markvardige, paa Fjerde Christians Kirke hvilende, over Hovedstadens Huse, Menneskevrimmel og Uro havede Bogsal - her var nu Nyerup(s), hans Flids, hans Arbeidsombeds, hans Virkekrafts rette Hiem. Chr. Molbech: Mindeord over Ove Malling og Rasmus Nyerup. (Kbh. 1830)

Accessionen blev nu lagt i fastere rammer. 1797 fik Universitetsbiblioteket ny instruks; bl.a. oprettedes en bibliotekskommission, hvor en professor fra hvert fakultet 
havde sæde. Herved forbedredes samarbejdet med universitetslærerne.

1821 gennemførtes en ny pligtafleveringsordning, som udstrakte afleveringspligten til at gælde hele landet. Af vigtige erhvervelser i disse år kan nævnes indlemmelsen af grev J.G. Moltkes store naturvidenskabelige bibliotek og i 1822 juristen J.H. Schous samling på næsten 1400 bd. 1814 havde man erhvervet orlogskaptajn Peter Schønnings samling, hvori fandtes bl.a. Chr. IV's stilebøger.

1807 er året for englændernes bombardement af København, og biblioteket var igen i overhængende fare. Men takket være Nyerup, Rahbek og en deling af Kronprinsens Livkorps blev skaderne minimale. Flere bomber gik gennem taget og eksploderede i bogsalen, men kun en enkelt bog med den sigende titel Defensor Pacis (Fredens Forsvarer) fik en fuldtræffer. Den fremvises den dag i dag i Fiolstræde.

Nyerup interesserede sig også levende for oldsager og samlede i biblioteket en hoben museumsgenstande, som blev til det oldnordiske museum, som siden indgik i Nationalmuseet. Dette "Kabinet for Fædrelandets Oldsager", bl.a. en halv snes store runesten, foruden utallige andre oldtidsgenstande, var jo et udmærket initiativ, men forøgede sandt at sige bibliotekets pladsproblemer, ligesom de besøgende, herunder utallige skolebørn, voldte bibliotekaren visse problemer! I hele 25 år havde dette spæde Nationalmuseum til huse på kirkeloftet. Først i 1832 blev samlingerne overflyttet til Christiansborg.

Iøvrigt var pladsproblemerne, selv uden oldtidsgenstandene, efterhånden særdeles mærkbare. Nye reoler blev opsat, hvilket gjorde rummet endnu mørkere. Forholdene var efterhånden utålelige både for publikum og for de tre fastansatte bibliotekarer og deres medhjælpere. Samtidig steg benyttelsen, bl.a. takket være Nyerups publikumsvenlige indstilling.

Blandt gæsterne i "Taarnet", som biblioteket kaldtes, var på den tid H.C. Andersen. Dette fremgår, foruden af Mit Livs Eventyr også af et digt, offentliggjort i Kiøbenhavns flyvende Post nr. 66, 1827, kaldet "Den rædselsfulde Time". Forfatteren forvilder sig i biblioteket og kommer "til at daane". Han vågner ved midnatstid:

Ak men nu slog Klokken tolv, det var falt at hore;

alle Boger rundt omkring saa jeg sig at rore.

Nogle skandtes, andre sang, Sproget var lidt blandet,

Som paa Babels-Taarn det klang ganske reent forbandet. 
og så videre. Men man mærker i det temmelig ubehjælpsomme ungdomsdigt kimen til eventyrdigteren.

Nyerup var iøvrigt, pligtopfyldende som han var, vist den første, som for alvor overholdt reglen om at holde forelæsninger i biblioteksbenyttelse, hvilket fremgår af hans pjece Om Bibliothekarforelesninger paa Universitetsbibliotheket $i$ Kjobenhavn med Fortegnelse over Bibliothekets Velgiorere.

Endvidere udgav han, sammen med J.E. Kraft, et meget benyttet forfatterleksikon og udfoldede i det hele store anstrengelser på det felt, vi i dag ville kalde Informations- og Dokumentationsvirksomhed.

I det hele betød den menneskealder, hvor Nyerup var leder af Universitetsbiblioteket, en overgang til moderne biblioteksbetjening. Han oprettede en ny alfabetisk katalog og nåede langt med en systematisk, iøvrigt samtidig med at Moldenhawer udførte sit katalogarbejde på Det kongelige Bibliotek.

De orientalske håndskrifter, som Rasmus Rask havde hjembragt fra Orienten, indlemmedes. Rask var inden han drog af sted, blevet underbibliotekar ved Universitetsbiblioteket. De ca. 40 håndskrifter indgår idag i Det kongelige Biblioteks Orientalske Afdeling, hvori de er klenodier. - En af Nyerups sidste embedshandlinger var at overtage af Videnskabernes Selskabs Bibliotek, en vigtig tilvækst, bl.a. takket være bytteforbindelser. Ved Nyerups død i 1829 rummede Universitetsbiblioteket ca. 100.000 bd. og pladsproblemerne var voksende.

Nyerups efterfølger blev Rask, men han døde allerede 1832 og nåede ikke at sætte sig nævneværdige spor som bibliotekar. Som sprogforsker har han som bekendt en stor plads i vor bevidsthed. Det gjorde derimod hans efterfølger, filologen J.N. Madvig, universitetsbibliotekar 1828-48.

1833 fik biblioteket et nyt reglement. Benytterkredsen er stadig begrænset til de akademiske borgere. "Skolediscipler og deslige unge Mennesker have ikke adgang". Katalogerne, hedder det, er mestendels forbeholdt bibliotekaren.

I universitetets årbog for 1842 gør Madvig sig nogle interessante tanker om Universitetsbiblioteket, et program for dets virksomhed. Praksis, viser det sig, er mere liberal end det ovennævnte reglement. Benyttelse af biblioteket bevilges i almindelighed alle, også selv om de ikke har forbindelse til universitetet "noget, hvorved undertiden Liberalitet og Taalmodighed sættes paa stærke Prøver", skriver han dog. Madvig påpeger, at lokaleforholdene er utidssvarende og personalet utilstrækkeligt. 
Udlånet er 12.000 bd. om året, og publikum forstyrrer det arbejdende personale!

Underbibliotekaren, under hvem katalogarbejdet sorterer, forstyrres ideligt af påtrængende lånere, der distraherer ham i hans vigtige arbejde. Overbibliotekaren må ofte forlade sin plads for at deltage i alskens forretninger, ja sågar udlånsarbejdet må han tage del i, "hvis Standsning og Ophold ellers ville indtræde". Vi nikker genkendende!

Madvig nævner også pligtafleveringen som et betinget gode. Der skal rykkes, og der skal katalogiseres, og det hele kræver tid. Katalogen fyldes med dårlige lejebiblioteksromaner og børnebøger, "lige ned til Grændsen af den laveste Smudslitteratur". Selektion har altid været et problem for Universitetsbiblioteket. Også da pligtafleveringen blev til rekvisitionsret. Nogle tog for lidt, andre for meget. Men den danske samling er dog rimeligt genuin. Takket være dygtige folk. Madvig mente iøvrigt også, at de videnskabelige biblioteker burde samarbejde om anskaffelsespolitikken, ja endog at Det kongelige Bibliotek og Universitetsbiblioteket burde have samme overordnede ledelse!

1848 afløstes Madvig af runologen P.G. Thorsen. Bogbestanden var nu oppe på 120.000 bd. med hovedvægt på naturvidenskaberne. Og udlånet var stigende. Således skriver A. F. Bergsøe i Den danske Stats Statistik III, 1848 dels om personalets velvillighed "til hvilket man længe skulle lede om Magen", dels om udlånet:

Når Universitetsbiblioteket anvendes mere end Det kongelige Bibliotek, så skyldes det også, at det forste ligger $i$ Byens Centrum, medens det andet ligger $i$ Udkanten af Byen, og dertil kommer, at man på Universitetsbiblioteket kan få Bogen nogenlunde med det samme, mens man på Det kongelige Bibliotek forst fär den en dag efter, at den er bestilt. Udlånet på Universitetsbiblioteket er 14-16.000 bind om året og derfor 3 gange så stort som udlainet fra Det kongelige Bibliotek.

Madvigs tanker om samarbejde vandt tilsyneladende genklang. I hvert fald skrev Kultusministeriet i juni 1848 til Konsistorium:

Det har allerede $i$ langere Tid varet erkjendt som et mindre heldigt Forhold, at de tre store offentlige Bibliotheker i Kjøbenhavn, det store kongelige Bibliothek, Universitetsbibliotheket og det classenske Fideicommisses Bibliothek, hidtil uden indbyrdes Forbindelse have forfulgt deres Formaal. Det maatte derfor saavel $i$ Videnskabens som $i$ Bibliothekernes egen Interesse ansees for magtpaaliggende at see disse offentlige Samlinger bragte saaledes $i$ indbyrdes Forbindelse, at de gjensidigen kunde understotte og supplere hinanden efter en for dem alle falles Plan.

En komité til kulegravning af de videnskabelige bibliotekers forhold, herunder 
spørgsmålet om en fælles ledelse for Det kongelige Bibliotek og Universitetsbiblioteket, blev nedsat. Komiteen afgav indstilling i november 1918, men nøjedes med at anbefale en fagdeling mellem de to store biblioteker, for Universitetsbibliotekets vedkommende med hovedvægt på naturvidenskaberne. Desuden skulle anskaffelserne koordineres. Man ser heri kimen til hovedfagbibliotekstanken. Samtidig bestemte det, at bibliotekerne skulle have åbent alle ugens hverdage. Det kongelige Biblioteks udlån skulle fremmes, hvilket dog fremkaldte en mindretalsudtalelse fra professor D.F. Eschricht som mente, at dette bibliotek skulle være præsenssamling og Universitetsbiblioteket udlånsbiblioteket. Disse tanker, som jo siden delvis er blevet realiseret, bekom overbibliotekar ved Det kongelige Bibliotek Chr. Molbech vel, idet de stemte med hans ideer om nationalbiblioteksforpligtelsen.

Spørgsmålet om samarbejdet mellem hovedstadens biblioteker blev atter aktualiseret i forbindelse med drøftelserne af en nybygning til Universitetsbiblioteket. Allerede Madvig havde peget på nødvendigheden af forbedrede lokaleforhold, og i 1843 nedsattes en komité, som i forlængelse af færdiggørelsen af Mallings universitetsbygning skulle tage stilling til den videre udbygning af universitetsfirkanten. Komiteen foreslog en biblioteksbygning ud mod Krystalgade, men planen strandede på økonomien og blev først, som vi skal se, taget op igen 8 år senere.

I mellemtiden og også efter indflytningen i Fiolstræde fortsatte diskussionen om forholdet mellem bibliotekerne. I forbindelse med planerne for Fiolstrædebyggeriet diskuteres ligefrem en fælles bygning for de to biblioteker, da også Det kongelige Bibliotek led af pladsnød, men sagen nød ikke fremme hos kultusminister A.S. Ørsted. Også Konsistorium fandt en sammenslutning "aldeles utilraadelig".

I stedet nedsattes et udvalg, bestående af Verlauff, P.G. Thorsen og Madvig. De forelagde deres betænkning i september 1854, og den vandt ministeriets tilslutning. Madvig førte det store ord.

Det skal dog nævnes, at Thorsen gik ind for en sammenslutning, hvorved der skulle dannes "et almindeligt Rigsbibliothek". Den endelige betænkning kan dog ikke anbefale en sammenslutning, navnlig fordi Universitetsbiblioteket er universitetets ejendom, men anbefaler dog samarbejde mellem de to institutioner.

Diskussionen fortsatte i 1860 af Christian Bruun i skriftet Det store kongelige Bibliothek og Universitetsbibliotheket. Han hæfter sig især ved katalogapparatet, som takket være Moldenhawer er i fin stand på Det kongelige Bibliotek. Anderledes 

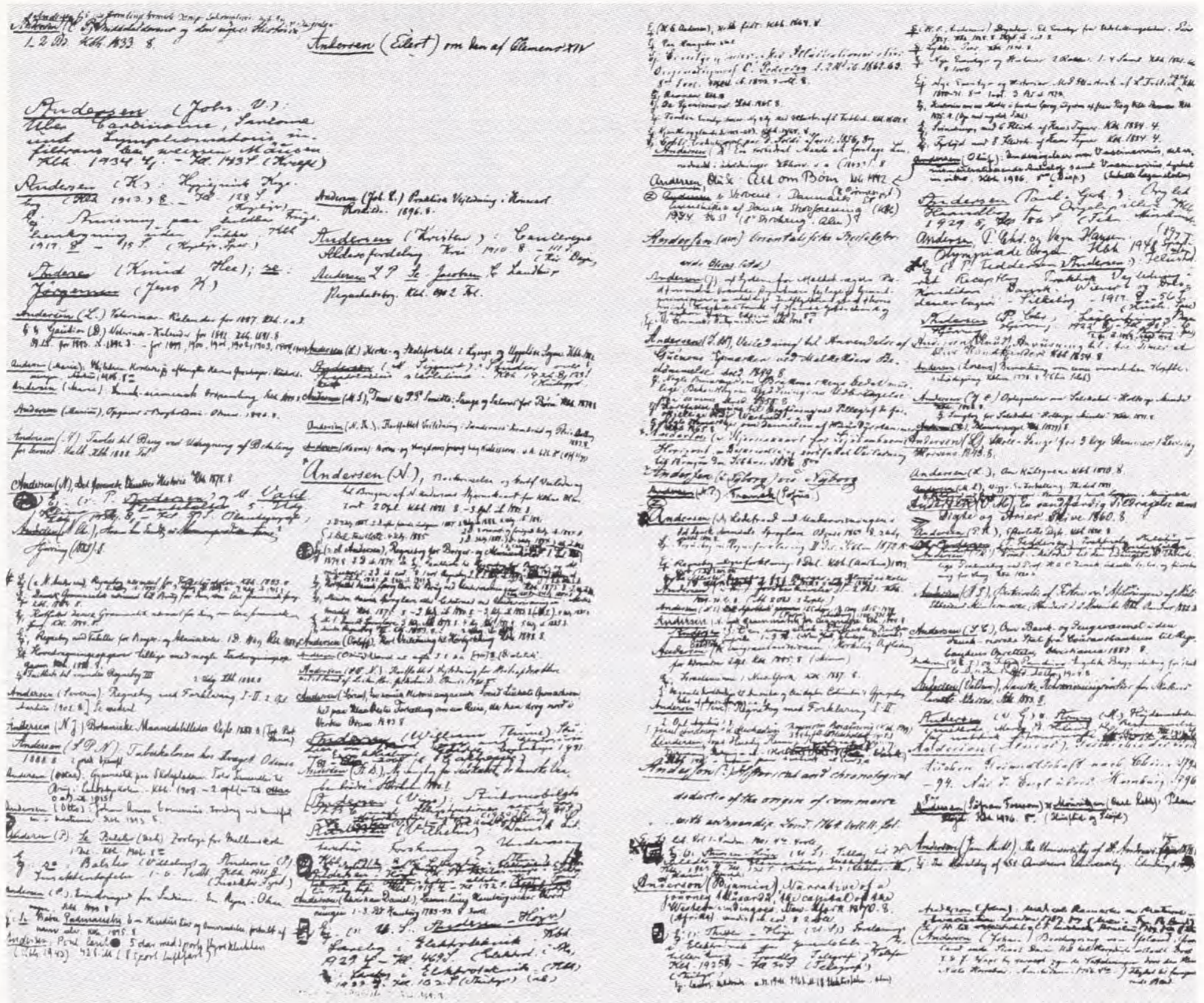

Et par af de efterhånden ganske overfyldte og uoverskuelige sider af den i Rasmus Nyerups tid anlagte alfabetiske katalog over Universitetsbibliotekets bogbestand.

med Universitetsbibliotekets kataloger, som i visse henseender er ganske uanvendelige. Han fremhæver endvidere, at Det kongelige Biblioteks udlån stadig er mindre, men dog stigende i forhold til Universitetsbibliotekets. Om læsesalsbenyttelsen hedder det, at KB's læsesal i 1859 besøgtes af 3.743 personer, UB's af ca. 3.800.

\section{1-1900}

Selv om Fiolstrædebygningen var rummelig, opstod der snart igen pladsproblemer, bl.a. på grund af indlemmelsen af Den polytekniske Læreanstalts Bibliotek og Det classenske Bibliotek. Herved forøgedes bibliotekets bogbestand med 25.000 bd., overvejende naturvidenskab. Samtidig med indflytningen i Fiolstræde udskiltes dog nogle landøkonomiske værker, som blev overført til Den kgl. Veterinær- og Landbohøjskoles bibliotek.

Bortset fra pladsproblemerne var det største problem efter indflytningen katalo- 
gerne, der som nævnt var kaotiske. Siderne i Nyerups gamle katalog var efterhånden overfyldte og fulde af tilskrivninger.

I Thorsens sidste embedsår påbegyndte man et stort anlagt katalogprojekt, som fuldførtes under hans efterfølger, Sophus Birket-Smith, overbibliotekar fra 1879 og i de følgende næsten 30 år. Igen en foregangsmand.

Det vigtigste var katalogprojektet. Som forbillede valgtes det såkaldte Halleklassifikationssystem, som anvendtes indtil 1971. Ved Birket-Smiths afgang i 1909 var 2/3 af bogbestanden nykatalogiseret i såvel en alfabetisk som en systematisk katalog efter dette system. Mange af de gamle håndskrevne kort findes stadig og står idag på KBSlotsholmen, hvor de kan studeres. KBFiolstræde og KBAmager har fået en microfiche-udgave.

Accessionen foregik i Birket-Smiths tid mere planmæssigt, om end anskaffelsesbudgetterne stadig var små. Hovedhjørnestenen var stadig pligtafleveringen. Håndskriftafdelingen forøgedes i denne periode med professorernes papirer, som udgjorde en vigtig kilde til universitetshistorien. Hertil kom privatarkiver fra kunstnere og andre kulturpersonligheder, bl.a. Søren Kierkegaard-samlingen og H.C. Ørstedarkivet. Også en kort- og billedsamling opbyggedes, alt nu overført til Slotsholmen.

Også lånereglerne blev liberaliseret, og reglementet fik en mere publikumsvenlig retning. Benyttelsen var jævnt stigende. Ca. 1880 var udlånet således o. 15.000 bd. pr. år og læsesalsbesøget på 6.500 personer, som benyttede 13.500 bd. Man ser, at udlånet har overgået læsesalsbenyttelsen, en liberal udlånspraksis, som altid senere er blevet fortsat. Kun antallet af medarbejdere sakkede som sædvanligt bagefter. Man diskuterede også udvidet åbningstid, men Birket-Smith påpegede, at en åbningstid til kl. 20 var en umulighed, al den stund biblioteket var uden kunstigt lys. 1898 indførtes lys på læsesalen, men 10 timers åbningstid kom først ca. 10 år senere.

\section{Det 20. århundrede}

Dette århundredes bibliotekshistorie er almen kendt og skal her gøres kort. Omkring århundredskiftet fortsætter debatten om forholdet mellem de to biblioteker, bl.a. i forbindelse med Det kongelige Biblioteks nybyggeri. Således spørger kirke- og undervisningsminister J.C. Christensen, under hvem bibliotekerne nu sorterer, om ikke en indlemmelse af Universitetsbiblioteket i det nye Kongelige Bibliotek kunne komme på tale. På Konsistoriums forespørgsel svarer overbibliotekar for Univer- 
sitetsbiblioteket Birket-Smith, at han finder en sammenslutning urealistisk, igen med henvisning til professorernes tarv. Han påpeger forskellighederne ved de to biblioteker, samt endelig Det kongelige Biblioteks "uheldige Beliggenhed paa et for den akademiske Verden afsides Sted". (Sic!)

I mellemtiden er det Classenske Bibliotek som nævnt blevet indlemmet i Universitetsbiblioteket, hvorved vægten er forrykket endnu mere i retning af naturvidenskab og medicin. Birket-Smith kan derfor godt gå med til en vis form for fagdeling.

Disse tanker realiseres endelig med Biblioteksbetænkningen af 1927. Den gennemfører en detaljeret fagdeling mellem de københavnske videnskabelige biblioteker, som hvad angår forholdet mellem Det kongelige Bibliotek og Universitetsbiblioteket betyder, at Universitetsbiblioteket nu bliver universitetets hovedbibliotek for medicin og naturvidenskab, mens Det kongelige Biblioteforuden at være nationalbibliotek varetager hovedfagforpligtelsen indenfor humaniora, teologi og samfundsfag. For de humanistiske fags vedkommende skal Universitetsbiblioteket i fremtiden kun fungere som "Orienterings- og Studiebibliotek, hvor de Studerende kunde have Adgang til den Haandbogs- og Oversigtslitteratur, som de har brug for til deres Studier, medens de for alle videregaaende Undersøgelser eller Specialstudier henvises til Det kongelige Bibliotek". Samtidig afløstes pligtafleveringen til Universitetsbiblioteket, som allerede anbefalet af Madvig, af en rekvisitionsret fra forlagene. Derved filtreredes meget unødigt materiale fra; til gengæld fik man et udvælgelsesproblem. I 1928 gennemførtes en udveksling af litteratur, ligesom hele Universitetsbibliotekets håndskriftsamling overgik til Det kongelige Bibliotek.

I 1938 deltes Universitetsbiblioteket i en 1. og 2. afdeling, idet medicin og naturvidenskab blev udflyttet til Nørre Allé, i den af Kristoffer Varming opførte nybygning. Tilbage i Fiolstræde var herefter de humanistiske, teologiske og juridiske samlinger, ialt vel på det tidspunkt ca. et par hundrede tusind bind, hvoraf de danske samlinger i kraft af pligtaflevering og rekvisitionsret udgjorde grundstammen. Hertil kom aviserne, hvor man fra gammel tid havde haft pligtaflevering af de københavnske. Nu deponeredes Det kongelige Biblioteks provinsaviser i kælderen i Fiolstræde, og der blev indrettet en avislæsesal i stueetagen.

Næste fase, som betegner den administrative koordinering, indtraf i 1943, da Svend Dahl blev rigsbibliotekar med overordnet ansvar for begge biblioteker. Denne konstruktion fortsatte indtil de såkaldte KOBUB-forhandlinger i 1980. I mellem- 
tiden havde UB 1 i 1978 åbnet en filial i forbindelse med Københavns Universitets byggeri på Amager. KOBUB udvalgsarbejdet mundede ud i 2 vigtige beslutninger: Rigsbibliotekarembedet blev adskilt fra funktionen som overbibliotekar for Det kongelige Bibliotek, og UB 2 blev udskilt som en selvstændig institution, Danmarks Natur- og Lægevidenskabelige Bibliotek (DNLB).

Resten er kendt stof. I forbindelse med Det kongelige Biblioteks moderniseringsprojekt nedsattes arbejdsgruppe 2, som skulle se på forholdet mellem Det kongelige Bibliotek og UB 1. Arbejdet mundede ud i sammenslutningen af de 2 institutioner til Det kongelige Bibliotek, vi kender i dag, med dets 3 betjeningssteder, hoveddomicilet på Slotsholmen og de to nærbiblioteker for hhv. humaniora og samfundsfag på Amager og i Fiolstræde.

Ved afskedsfesten for overbibliotekar Torben Nielsen i 1988, som fandt sted i Universitetets festsal, holdt undertegnede en tale, hvori jeg citerede Erik Aschengreen (Biblioteker på vor vej, udg. i anl. af Danmarks Forskningsbiblioteksforenings 10-års jubilæum, 1988). Det hedder heri afslutningsvis om Universitetsbiblioteket i Fiolstræde:

En sommerdag i 1987 skulle jeg til et mode på hans kontor med de hoje paneler. Vi var fortravlede. Så meget skulle nås inden ferien, og Torben Nielsen syntes, vi trangte til en lille hjertestyrkning, som han fandt frem fra mahogniskabet. Vi censurerede nogle specialer, men fik også tid til at tale om andet. Biblioteksproblemer, forestaiende sommerog rejseplaner og som altid et par ord om Paris, der har vores hjerte. Torben Nielsen blev kaldt ud et ojeblik, og jeg sad alene $i$ den sorte hestehärsstol og kiggede gennem det hoje vindue på Holbergs tre, der vajede blidt for vind og sol ovre i gården ved domprovstens bolig, der er genbo til biblioteket, og hvor Holberg residerede engang. Tredive är efter scenen med Robert Neiiendam oplevede jeg - som utallige gange i de mellemliggende ar - at Universitetsbiblioteket er et sted, hvor man forsker, lever, henter boger og bliver klogere, men også et sted, hvor mennesker modes $i$, hvad man i dag kalder et miljo. En bogernes verden. En menneskeverden.

Jeg udtrykte ønsket om, at det måtte det vedblive at være, og det gør jeg stadig. Og så et levende bibliotek. Det overlades hermed til jer, som kommer efter. Stat rosa pristina - hvilket er udlagt: Den fordums rose består ...

\section{Litteratur}

Hovedkilden til den almindelige bibliotekshistorie er jubilæumsskriftet Kobenhavns Universitet 14791979, bd.4, Gods, bygninger, biblioteker. Red. Svend Ellehøj og Leif Grane. Kbh. 1980. Denne kilde er den nyeste, hvori Harald Ilsøe, Palle Birkelund og Torben Nielsen har givet fortræffelige fremstillinger. I det omfattende noteapparat i dette værk kan findes henvisninger til den øvrige litteratur. 